\title{
TUMOR ocular surface squamosa \\ TINJAUAN PUSTAKA MENGENAI ETIOPATOGENESIS, DIAGNOSIS KLINIS, DAN HISTOPATOLOGIS
}

\author{
Esti Mahanani ${ }^{1}$, Artati Sri Rejeki ${ }^{1}$ \\ ${ }^{1}$ Departemen Ilmu Kesehatan Mata Fakultas Kedokteran Universitas Islam Indonesia Sleman Yogyakarta
}

\begin{abstract}
ABSTRAK
Tumor ocular surface squamosa neoplasia (OSSN) merupakan salah satu tumor terbanyak di bidang mata dengan angka rekurensi dan morbiditas yang tinggi. Tumor ini memiliki gambaran klinis bervariasi. Diagnosis ditegakkan melalui histopatologi dari hasil eksisi biopsi. Istilah OSSN meliputi displasia ringan dalam bentuk conjunctival intraepithelial neoplasia dan carcinoma in situ serta dalam bentuk metastasis yaitu karsinoma sel skuamosa invasif. Tumor ini memiliki etiologi multi-faktorial dengan interaksi beberapa faktor seperti paparan radiasi ultraviolet, karsinogen kimia, kondisi kekurangan vitamin A dan infeksi dari beberapa virus tetapi kondisi individual memang belum jelas. Infeksi human immunodeficiency virus (HIV) dan human papilloma virus (HPV) diduga paling berperan dalam kondisi ini. Tren perubahan terlihat dalam presentasi klinis dan prognosis yang memburuk pada pasien dengan OSSN dengan infeksi HIV yaitu munculnya bentuk karsinoma mucoepidermoid dan karsinoma sel spindle yang sangat agresif. Pemeriksaan oftalmologi umum wajib dilakukan untuk diagnosis klinis dengan slitlamp, sedangkan pemeriksaan penunjang seperti gonioskopi, visualisasi dengan anterior optical coherence tomography (OCT) dan confocal microscopy mungkin diperlukan pada beberapa kasus. Penanganan utama adalah diagnosis tepat dan penanganan sedini mungkin untuk prognosis yang baik sehingga peran dokter pada pelayanan primer sangat penting. Operasi pengambilan tumor, kemoterapi topikal, brachytherapi dan imunoterapi adalah berbagai modalitas pengobatan yang dikombinasikan dan menunjukkan hasil yang menjanjikan pada kasus yang agresif rekurent dan besar.
\end{abstract}

Keyword : Ocular surface squamous neoplasia, conjunctival intra epithelial neoplasia, carcinoma in situ, etiopatogenesis, diagnosis klinis, histopatologi 


\section{ABSTRACT}

Tumor ocular surface squamous neoplasia (OSSN) is one of the most ocular tumor with high reccurence and morbidity. This tumor has a varied clinical presentation, and the diagnosis is established through histopathology of excision biopsy results. The diagnosis of OSSN includes a spectrum of conditions ranging from mild squamous dysplasia of the conjunctiva through moderate dysplasia, carcinoma in situ (CIS), and, in the advanced stage, invasive squamous carcinoma. This lesion has a multi-factorial etiology with interplay of several factors like exposure to ultraviolet radiation, various chemical carcinogens and viral infections, however role of individual agents is not well understood. Human immunodeficiency virus and human papilloma virus are the most likely suspects in this condition. Trends changes seen in clinical presentation and worsening prognosis in patients with HIV infection as a form of mucoepidermoid carcinoma and spindle cell carcinoma which is a very aggressive. General ophthalmology examination must be done for the clinical diagnosis with slitlamp and gonioskopi in the specific condition. Visualization of the anterior optical coherence tomography (OCT) and confocal microscopy may be necessary in some cases. The main treatment is proper diagnosis and treatment as early as possible for a good prognosis so that the role of physicians in primary care is very important. Tumor removal, topical chemotherapy, brachytherapi and immunotherapy are the various treatment modalities for better result in aggressive, recurrent and larger tumours.

Keywords : Ocular surface squamous neoplasia, conjunctival intra epithelial neoplasia, carcinoma in situ, etiopatogenesis, clinical features, histopathology

\section{PENDAHULUAN}

Tumor ocular surface squamosa neoplasia yang akan kita sebut dengan OSSN merupakan salah satu spektrum tumor terbanyak dibagian mata. OSSN merupakan ocular surface tumor dengan angka kejadian tertinggi, dan merupakan 3 tumor terbanyak dari seluruh tumor okuloorbital selain melanoma dan limfoma $1,2,3,4$. Saat ini tumor ini masih menjadi permasalahan yang cukup besar dibagian mata karena angka morbiditas dan mortalitasnya yang tinggi, serta kecacatannya yang bisa menginvasi intraokular. Angka rekurensi tumor ini berkisar $\pm 43-51 \%$ (pada 10 tahun) dengan angka mortalitas yang tinggi $( \pm 15-30 \%$ pada 10 tahun.). ${ }^{5}$ OSSN meliputi semua semua lesi neoplastik intraepitel konjungtiva (CIN) dan karsinoma sel skuamosa invasif (SCC) dari permukaan okular bola mata. Selain usia lanjut dan jenis kelamin laki-laki, faktor risiko utama lainnya yang terkait dengan patogenesis adalah paparan ultraviolet, merokok, dan virus papiloma manusia ${ }^{3,6}$ Beberapa sumber menambahkan bahwa kondisi imunodefisiensi dan infeksi HIV juga ikut berperan terhadap kejadian dan perburukan $\operatorname{OSSN}^{7,8,9}$. 
Dari berbagai etiopatogenesis tumor Uganda Afrika dan merupakan yang diatas, beberapa penelitian sudah tertinggi ${ }^{10}, 1,9 / 100.000$ penduduk per membuktikan keterkaitan dengan OSSN, tahun di wilayah metropolitan Brisbane tetapi memang belum bisa dipastikan. Australia, ${ }^{11}$ dan 0,3 juta per tahun di

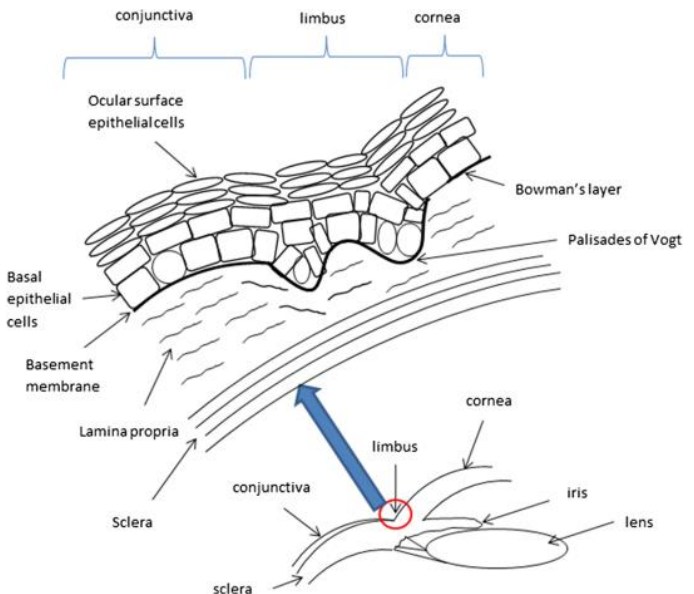

A

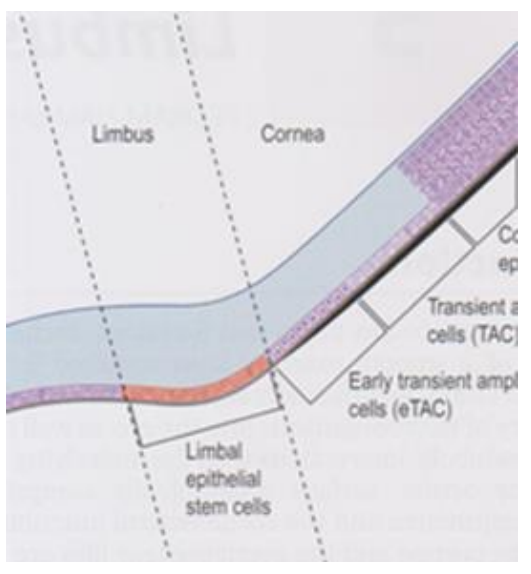

B

Gambar 1.Gambar skematik (A) Anatomi limbus kornea dan konjungtiva. (B) Daerah limbus kornea merupakan asal terbanyak tumor primer dikarenakan adanya limbal stem cell ${ }^{7,1}$

Diagnosis klinis sampai saat ini tetap sesuai dengan gambaran histopatologi yang disesuaikan dengan kondisi klinis. Tinjauan pustaka ini akan mengemukakan berbagai teori tentang etiopatogenesis OSSN yang multifaktorial dengan beberapa faktor predisposisi serta diagnosis klinis patologis.

\section{ASPEK EPIDEMIOLOGI}

Secara epidemiologi tumor ini termasuk jarang walaupun merupakan salah satu tumor terbanyak di bagian mata. Ratarata insidensi OSSN pada konjungtiva dan kornea diperkirakan 3,5/ 100.000 di
Amerika Serikat. ${ }^{11,6}$ Rata-rata usia terjadinya OSSN adalah 56 tahun, dengan rentang usia 4-96 tahun. Usia pasien muda ditemukan pada pasien dengan infeksi HIV dan pada penderita Xeroderma pigmentosum. ${ }^{6}$ Di Indonesia sendiri data insidensi OSSN memang belum pernah diteliti.

\section{FAKTOR PREDISPOSISI}

Tumor pada permukaan okular bola mata berlokasi primer dari konjungtiva atau kornea. Pada konjungtiva asal tumor bisa berasal dari epitel atau dari stroma 
sedangkan dari kornea tumor bisa berasal primer dari epitel tapi sangat jarang dari stroma. $^{12}$

Cedera genetik pada sel-sel yang bersifat proliferatif seperti epitel dan limbal stem cell pada perbatasan kornea dan konjungtiva akan menyebabkan gangguan kendali fungsi selular, dan proliferasi lebih kanjut bisa bersifat neoplastik. ${ }^{6,1}$ Beberapa faktor dicurigai terlibat dalam pengembangan OSSN. Gangguan fungsi limbal stem sel diduga berperan dalam patogenesis OSSN karena sel ini sangat aktif. ${ }^{6}$ Kerusakan limbal stem cell ini bisa terjadi karena agen mutagenik seperti sinar radiasi UV B, paparan produk minyak bumi, rokok, bahan kimia seperti trifluridine, arseninikum, cedera pada mata misalnya pasca operasi okular, kekurangan vitamin A, pigmentasi pada rambut, kerusakan DNA pada pasien Xeroderma pigmentosum, infeksi dengan HIV, HPV dan beberapa kondisi imunodefisiensi lainnya. ${ }^{6,13,14}$

\section{Peran agen infeksi pada kejadian OSSN}

Mengingat bahwa agen infeksi berkontribusi sekitar $18 \%$ dari kanker pada manusia di seluruh dunia, beberapa ahli mata berpikir penting untuk mengeksplorasi peran agen infeksi juga dalam neoplasma dari adneksa okular primer yang meliputi keganasan dari konjungtiva, kelenjar lakrimal, kelopak mata, dan orbita. Dengan menjelaskan mekanisme keganasan oleh agen infeksius yang berkontribusi pada kondisi onkogenesis maka hal ini penting dan diharapkan bisa dipertimbangkan dalam manajemen, perawatan, dan pencegahan neoplasma ini. ${ }^{15,7}$ Pengobatan antibiotik dan vaksin terhadap agen infeksius mungkin menjadi pilihan masa depan sehingga bisa mengurangi kemungkinan terapi tradisional operasi, radiasi, dan kemoterapi yang menjadi beban besar. $^{15,16,3}$ Tidak seperti keganasan lain dengan studi sampel besar yang tersedia, analisis neoplasma adneksa okular masih menjadi tantangan karena mereka relatif jarang. Selain itu, agen infeksi diduga tampaknya menampilkan variasi geografis yang sangat besar yang menyebabkan banyak perdebatan mengenai hubungan dari satu organisme versus lain terhadap suatu kejadian keganasan. ${ }^{15}$

\section{Human papilloma Virus (HPV)}

$$
\text { Human Papiloma Virus (HPV) }
$$

terutama tipe 16 dan 18 pada beberapa studi secara jelas telah disebutkan berperan penting terhadap patogenesis tumor konjungtiva. ${ }^{14,4,8,9,13}$ Sedangkan pada kejadian OSSN atau kondisi kegananasan konjungtiva studi yang meneliti memang 
lebih sedikit, tetapi beberapa bukti ilmiah menyebutkan peran penting HPV pada patogenesis OSSN. ${ }^{15,4,8,16}$ Chauchan et al (2012) memeriksa 64 hasil biopsi konjungtiva dan didapatkan 7 sampel dengan HPV 16 positif dimana 6 diantaranya marupakan pasien dengan OSSN. ${ }^{(4)}$ Simbiri et al (2010) meneliti dari 28 sampel biopsi konjungtiva didapatkan $70 \%$ positif terinveksi HPV tetapi juga disertai infeksi virus lain. ${ }^{9,4}$ Di Yogyakarta juga pernah diteliti dari 15 sampel tumor konjungtiva didapatkan 7 sampel positif HPV. ${ }^{16}$ Beberapa bukti yang membingungkan adalah bahwa ditemukan juga DNA HPV pada kedua mata pada OSSN unilateral, adanya DNA HPV pada mata normal, dan tetap adanya DNA HPV walaupun OSSN sudah di eradikasi. ${ }^{17,3}$ Dari ketiga penelitian ini, dalam keterlibatan etiologi multifaktorial peran HPV diduga kuat memberikan pengaruh pada patogenesis OSSN walaupun tidak berdiri sendiri dan memerlukan kofaktor seperti infeksi virus lain dan UV B. ${ }^{18}$

\section{Human Immunodeficiency Virus (HIV)}

Infeksi HIV juga menjadi salah satu faktor yang diduga kuat terlibat dalam etiopatogenesis OSSN. ${ }^{14,13,19}$ Peningkatan kejadian OSSN, sejak pandemi HIV meningkatkan kecurigaan bahwa infeksi
HIV meningkatkan risiko OSSN. Di Afrika yang merupakan daerah dengan kondisi infeksi HIV yang tinggi, OSSN telah diakui terkait dengan HIV dengan cara merusak system kekebalan tubuh yang merupakan barrier terhadap tumor. ${ }^{20}$ Usia rata-rata di mana pasien datang dengan karsinoma skuamosa invasif lebih muda yaitu antara 32 sampai 37 tahun, dan proporsi pasien wanita berkisar dari $55 \%$ sampai $70 \% .^{10}$ Infeksi HIV kini ditetapkan sebagai faktor risiko untuk pengembangan OSSN berdasarkan studi dari Rwanda, Malawi, dan Uganda. ${ }^{6,10}$ Suatu penelitian di Afrika menemukan bahwa $70,6 \%$ pasien dengan OSSN positif terinfeksi HIV ${ }^{20}$ Infeksi HIV berpotensi menjadi suatu agen onkogenik selain beberapa virus lain yaitu HPV, Kaposi sarcoma-associated herpes virus (KSHV) and Epsteine Barr virus (EBV) dengan meningkatkan transmisinya kedalam sel target. ${ }^{14}$ Sebuah laporan dari Botswana menambahkan bahwa beberapa infeksi virus multipel meningkatkan kondisi terbentuknya OSSN dan pterigium. ${ }^{9,21}$ Penting menjadi perhatian adalah karena OSSN yang terjadi pada pasien HIV bersifat agresif dan invasif dan membutuhkan penanganan radikal seperti enukleasi atau bahkan eksenterasi sehingga 
kondisi ini menjadi suatu permasalahan yang serius.

\section{Sinar Ultraviolet}

Berbagai menunjukkan hubungan linear antara paparan radiasi ultraviolet dan pengembangan OSSN. ${ }^{6,22,3,23,13}$ Jenis kelamin laki-laki dengan aktivitas luar ruangan yang tinggi, lesi bagian temporal yang lebih terpapar sinar matahari menjadi lebih umum dan lebih agresif dari lesi nasal. $^{7,13}$ Selain itu, insiden yang lebih tinggi pada individu berkulit putih dan insidensi tinggi pada kulit aktinik membuat paparan sinar matahari sebagai pemicu utama kondisi OSSN. Tingkat risiko tergantung pada jenis sinar UV, intensitas paparan, jumlah kumulatif paparan dan kuantitas cahaya, serta kondisi melanin. Bagian UV dari matahari dapat dibagi menjadi tiga rentang panjang gelombang UVA (320-400 nm), UVB (280-320 nm), dan UVC (200-280 nm). Dari jumlah tersebut, UVB diyakini paling bertanggung jawab untuk induksi berbagai kanker permukaan kulit dan mata. ${ }^{6}$ Sinar matahari yang mengandung sinar ultraviolet $\mathrm{B}$ merupakan suatu agen imunosupresor dimana tidak hanya mempengaruhi kondisi permukaan tubuh yang terkena paparan tetapi juga secara sistemik. Sinar UV- B menyebabkan kerusakan DNA dan pembentukan pyrimine dimers, yang merupakan penyebab utama melanoma pada manusia. ${ }^{22,23}$ Kegagalan atau keterlambatan dalam perbaikan dapat menyebabkan mutasi somatik dan onkogenesis. Selain itu, radiasi UV B adalah mutagenik untuk p53 (protein penekan tumor) di host, yang mengatur siklus sel dan fungsi sebagai penekan tumor 7,23 .

\section{Kondisi Imunodefisiensi}

Kondisi imunodesiensi diduga kuat berperan dalam patogenesis OSSN. ${ }^{23,3,7}$ Tumor imunologi menganggap bahwa selsel tumor mengekspresikan antigen seperti mp53 dan HPV protein yang membedakan mereka dari sel normal. Sistem kekebalan tubuh mencegah pembentukan tumor dalam 3 cara yaitu penghapusan atau penekanan infeksi virus, mencegah pembentukan lingkungan pro-inflamasi dan khusus mengidentifikasi dan menghilangkan sel-sel yang mengekspresikan antigen-tumor. ${ }^{(20)}$ Sistem kekebalan tubuh juga berperan dalam proses yang lebih umum disebut tumor immuno-editing. Immunoediting adalah proses ganda di mana sistem kekebalan tubuh mungkin baik menekan pertumbuhan tumor dengan menghancurkan atau menghambat pertumbuhan sel-sel 
kanker atau tidak sengaja mempromosikan perkembangan tumor dengan memilih selsel tumor yang lebih mungkin untuk bertahan hidup. Pada intinya sistem kekebalan tubuh gagal untuk membendung tumor, sel tumor menyebar luas dan akan menyebabkan ekspansi tumor yang tidak terkendali. ${ }^{7}$

\section{Kondisi defisiensi vitamin A}

Kondisi defisiensi vitamin A juga diduga berperan dalam patogenesis OSSN. melalui modifikasi epigenetik dari histon atau dengan mengubah struktur kromatin untuk menghapus batang sel dari sel induk pluripotential dalam hal ini adalah limbal stem cell. $^{1}$ Suatu peneliti kemudian berhipotesis bahwa kekurangan vitamin A memiliki tiga efek yaitu merusak integritas epitel permukaan sehingga menyebabkan kondisi mikro - abrasi untuk jalan masuk infeksi HPV, mengarah ke kondisi immunodefisiensi, dan ketidakseimbangan

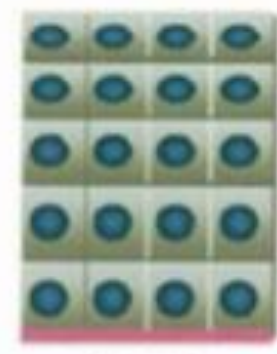

Normal

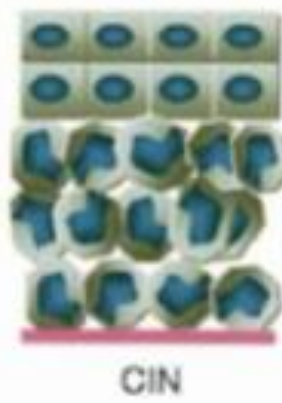

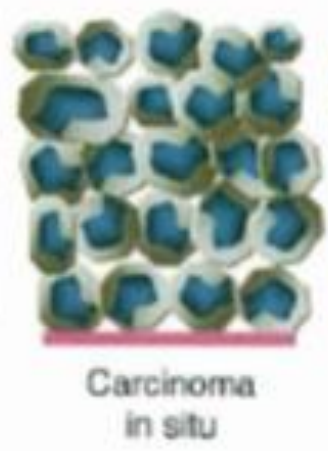

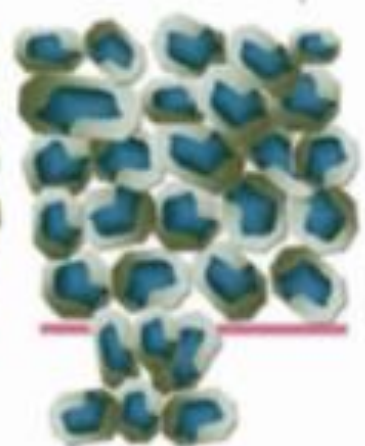

Invasive carcinoma

Gambar 2. Gambaran skematik tumor, perbedaan antara sel normal sampai arsinoma invasif ${ }^{13}$

7,1,24 Vitamin A membantu menjaga integritas permukaan okular bola mata. Kekurangan vitamin A akan berhubungan dengan metaplasia sel skuamosa konjungtiva. Vitamin A juga bertindak sebagai mukosa dan penambah kekebalan sistemik melalui immunohomeostasis dari pembantu sel T dan sel T CD4. Sel-sel ini mempromosikan diferensiasi sel puntat diferensiasi sel induk limbal stem cell yang bisa menjadi kondisi karsinogenik. ${ }^{7}$

\section{GAMBARAN KLINIS OSSN}

Gambaran klinis tumor ocular surface squamous terbagi dalam 2 spektrum yaitu CIN dan tumor invasif. CIN (conjunctival intraepithelial neoplasia) terbagi dalam derajat displasia ringan 
sampai berat. Jika tumor telah menembus kornea pada limbal stem kearah lapisan epitel maka sudah menjadi kondisi konjungtiva bulbi pada kondisi awal. Lesi carcinoma in situ (CIS). Kondisi tumor ini ditandai dengan batas meninggi terlihat yang sudah menembus membran basalis di atau dekat limbus, warna putih keabukonjungtiva dikategorikan sebagai abuan dengan pembesaran pembuluh darah. karsinoma yang sangat berpotensi ${ }^{25,13,24}$ Rose Bengal atau pewarnaan hijau
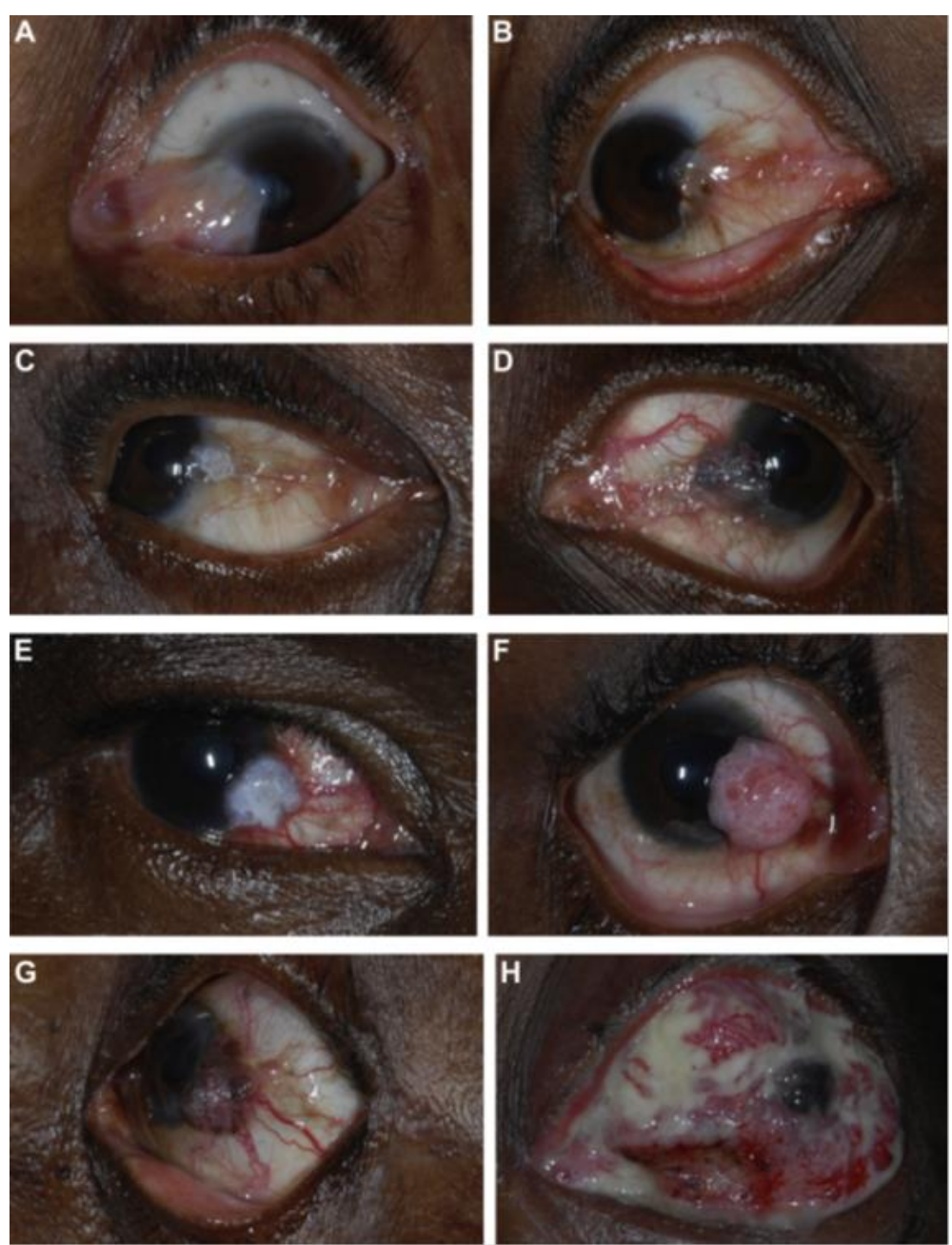

Gambar 3. Gambaran berbagai lesi di permukaan ocular (A) Pterigium grade 2 (B) Conjunctival intraepithelial neoplasia CIN grade 1 (C) CIN grade3 (D) Carcinoma in situ CIS (E) Squamous cell carcinoma (SCC) grade 1 (F) SCC grade 2 (G) SCC grade 3 (H) SCC dengan invasi ke orbita ${ }^{19}$

metastasis intraokular, intraorbital dan Lissamine dapat membantu dalam sistemik melalui limfonodi. ${ }^{8,13,6}$ menggambarkan luas dan kedalaman lesi.

OSSN secara klinis tampak sebagai Pada sisi kornea lesi dapat dilihat sebagai lesi konjungtiva diawali didaerah limbus kekeruhan dari epitel, dengan lesi sedikit 
terangkat dibandingkan dengan epitel yang normal. Cara terbaik adalah dengan pemeriksaan retroillumination. $^{23,13}$
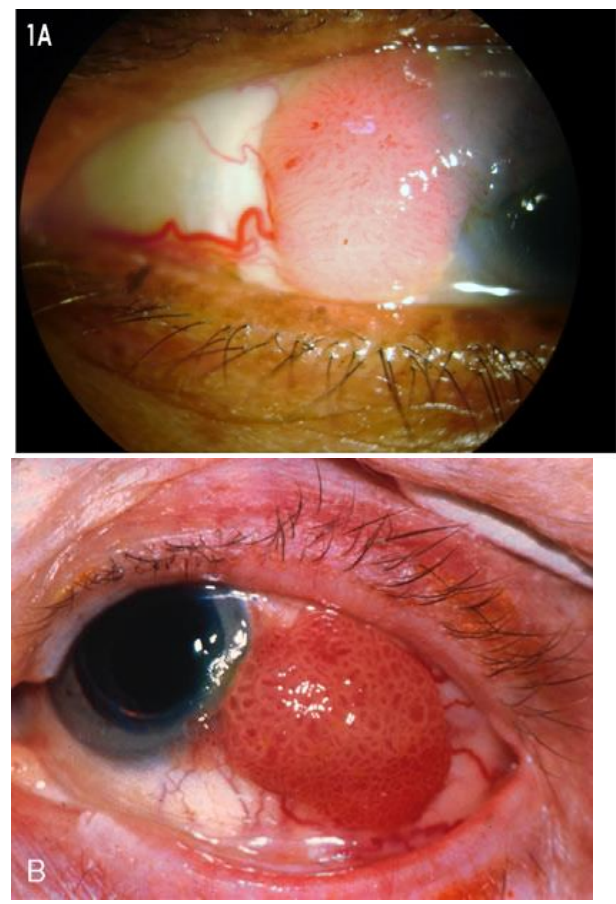

1,23,6 Kadang terdapat kesulitan dalam membedakan CIN dan Squamous cell carcinoma jika dilihat dari pemeriksaan

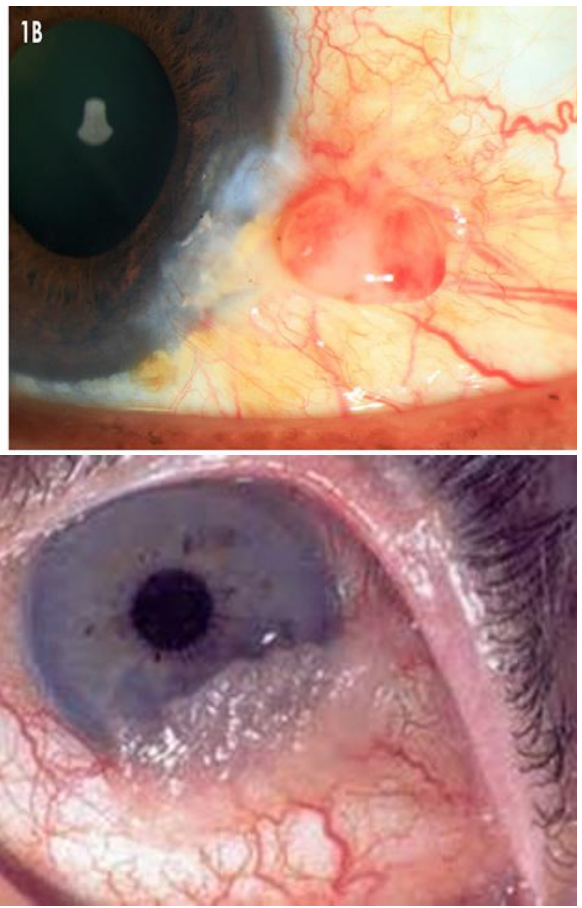

Gambar 4. Beberapa variasi lain manifestasi klinis OSSN (A) OSSN tipe papiler dilihat dengan slitlamp dengan pembesaran pembuluh darah yang prominen (B)Lesi CIN globular warna merah muda dengan perbesaran pembuluh darah. Tampak seperti gambaran pterigium (C) OSSN luas yang sampai ke kornea (D) gambaran lesi leukoplakia dengan pembesaran pembuluh darah abnormal $^{6,12}$.

OSSN adalah tumor yang tumbuh lambat dengan keganasan sedang yang jarang bermetastasis luas atau hanya bersifat invasi lokal ke daerah periokular atau intraokular . Tiga jenis morfologi yang sering adalah bentuk gelatinous, leukoplakia dan papilliform. Pada praktek klinis, jenis gelatinous adalah yang paling umum dan memiliki kecenderungan untuk pertumbuhan yang cepat dan menyebar. fisik saja karena ukuran tidak menentukan jenis histopatologi. ${ }^{1}$

Gambaran tumor yang agresif pada OSSN ini memang jarang terjadi tetapi perlu menjadi kewaspadaan. Jenis karsinoma mukoepidermoid yang sangat ganas bisa terjadi pada pasien usia tua atau infeksi HIV, dan bisa menginvasi intraokular dan intraorbital. ${ }^{6,19,10}$ Jenis tumor ini sangat agresif, dilaporkan 
rekurensinya dalam suatu studi antara 84- spatula, pemeriksaa sitologi dengan 100\%. ${ }^{6}$ Gambaran musin yang diproduksi mikroskop konfokal, OCT dengan resolusi sel tumor akan menunjukkan gambaran sangat tinggi dan yang utama adalah kistik oranye. Karsinoma sel spindle juga dengan pemeriksaan histopatologi biopsi
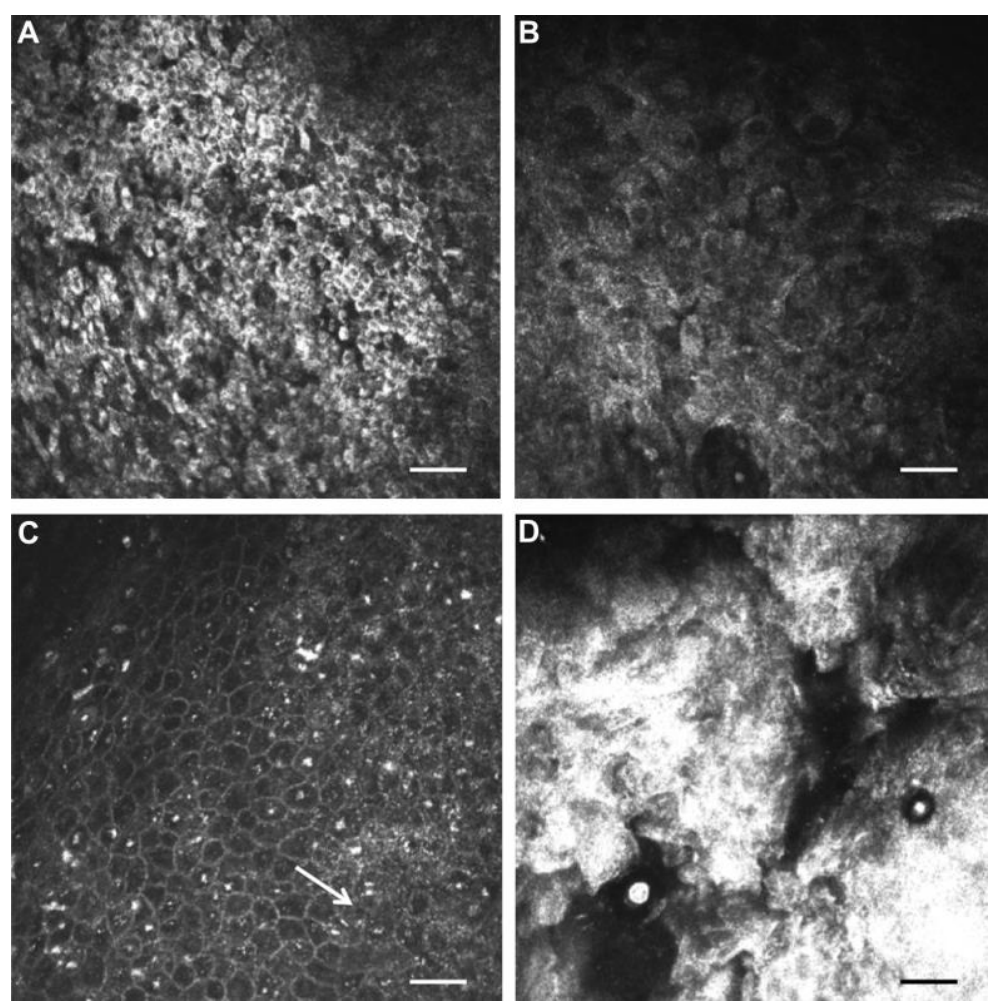

Gambar 5. Gambaran invivo OSSN dengan mikroskop konfokal. Tampak A. sel hiperefeltif kecil B. sel hiper-reflektif dengan ukuran bervariasi C. gambaran sel mitotik D. sel keratinisasi $^{19}$

merupakan bentuk ganas lain yang bisa bermetastatis jauh. Kedua jenis tumor ini harus ditangani dengan pembedahan dengan batas bebas tumor yang lebar untuk menghindari sisa sel tumor yang tertinggal. ${ }^{6}$

\section{PENEGAKAN DIAGNOSIS}

Penegakan diagnosis bisa dilakukan melalui sitologi usapan tumor dengan eksisi. $^{1,19}$

Standar baku emas penegakan diagnosis untuk seluruh tumor ocular surface adalah dengan pemeriksaan histopatologi dari spesimen pasca biopsi eksisi. ${ }^{5,19,6}$ Pemeriksaan oftalmologi secara lengkap wajib dilakukan. Pemeriksaan dengan slitlamp untuk diagnosis gambaran klinis penting dilakukan, karena gambaran 
OSSN akan terlihat jelas yaitu pembesaran diawali di sekitar limbus kornea dengan warna merah muda, leukoplakia, gambaran khas crockshaw, tampak seperti sisik ikan, dengan pelebaran pembuluh darah sekitas massa. $^{13}$ Pemeriksaan untuk diagnosis metastasis seperti gonioskopi pada kecurigaan invasi intraokular, MRI untuk kecurigaan intaorbita atau intrakranial, dan pemeriksaan limfonodi pada kecurigaan metastasis jauh harus dipertimbangkan sesuai kondisi klinis pasien 25 .

\section{DIAGNOSIS BANDING}

Tumor ocular surface squamous paling sering didiagnosis banding dengan pinguecula, pterigium, actinic keratosis, papilloma squamous dan episkleritis pada tahap awal. ${ }^{26}$ Hirst et al meneliti sejumlah 533 spesimen kasus pterigium dan didapatkan 9,8\% dengan tanda displasia sel. Ini membuktikan bahwa seharusnya seluruh spesimen pterigium diambil untuk tetap diperiksa histopatologis pada saat pengambilan. $^{21}$

\section{GAMBARAN HISTOPATOLOGI OSSN}

Gambaran pre invasif OSSN diklasifikasikan sebagai bentuk ringan, sedang dan berat berdasarkan perubahan epitel oleh displasia sel yang tidak matur. Displasia ringan jika displasia menyentuh sepertiga epitel. CIN moderat adalah jika sel abnormal sampai sepertiga bawah epitel, dan CIN berat jika sudah meliputi seluruh lapisan epitel dengan kehilangan polaritas

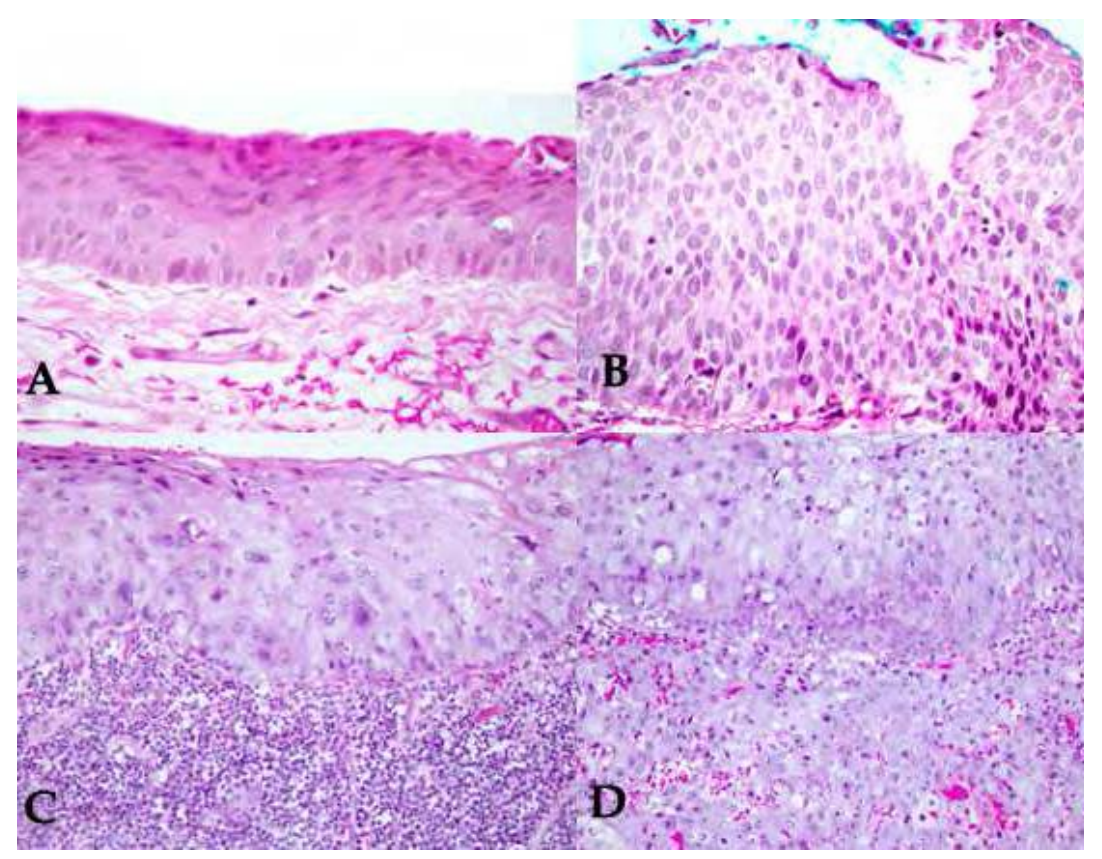

Gambar 6. Gambaran histologi (A)Dysplasia ringan (B)Dysplasia berat (C) carcinoma in situ (CIS) ${ }^{\mathbf{2 7}}$ 

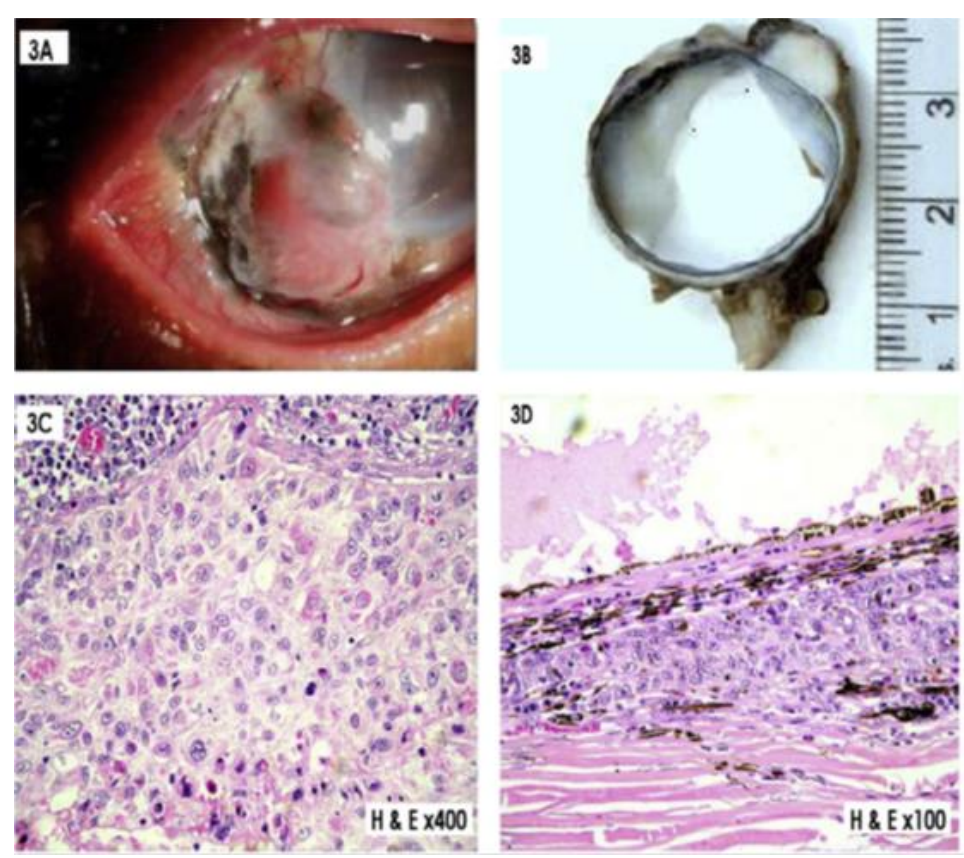

Gambar 7. Contoh kasus OSSN yang menginvasi intraocular A) Gambar slitlamp menunjukkan penipisan sklera dan perforasi dari jam 7-11 didaerah temporal limbus B) Pasca enukleasi , massa epibulbar menembus kornea dan sclera C) Pewarnaan haematoxylin-eosin menunjukkan karsinoma sel squamous dengan sel anaplastik, dan keratinisasi D)Histopatologi massa menunjukkan infiltrasi sklera dan

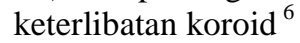

sel normal dan sudah disebut karsinoma invasif. $^{24}$ Pada Squamous cell carcinoma invasif, sel displastik menginvasi membran basalis masuk ke substantia propia konjungtiva. Ketika kornea terlibat, lesi tidak menginvasi membran Bowman kecuali rusak oleh suatu operasi okular. ${ }^{24,13}$

Kebanyakan OSSN dengan tipe invasif bersifat well differentiated, dengan diskeratosis dan sel-sel keratinisasi (horn cells). Tumor dengan well differentiated ini menunjukkan variasi sel pleomorfisme dengan nucleus hiperkromatosis, nukelus prominen, dan gambaran mitosis kadang dengan hiperparakeratosis dan parakeratosis. Variasi lain adalah dengan perilaku sel yang lebih agresif dengan karsinoma sel spindle, mucoepidermoid, dan adenoid squamous cell carcinoma. ${ }^{24}$

\section{PENANGANAN}

Pada dasarnya penanganan tumor pada ocular surface adalah sama untuk semua jenis baik itu papilloma, Squamous cell carcinoma ataupun melanoma yaitu pengangkatan tumor dengan batas margin bebas tumor yang lebar. Tumor pada daerah ocular surface ini walaupun kecil dan jarang mengancam nyawa tetapi morbiditas, dan rekurensi cukup berbahaya sampai mengancam pengambilan bola mata. Eksisi tumor baik sendiri atau dikombinasikan dengan terapi medis adalah yang dianjurkan. ${ }^{24}$ 
Beberapa ahli tumor mata topikal penting digunakan dengan ditambah menyarankan pengambilan tumor sedini kombinasi salep dan lumbrikan. ${ }^{28,24}$ mungkin dengan aplikasi alkohol, 2. Kemoterapi topikal pemberian anti metabolit dan Cryotherapy Penggunaan mitomycin $\mathrm{C}$ topikal durante operasi untuk membunuh sel tumor $\quad 0,02 \%-0,04 \%$ 4x sehari selama 1-3 minggu sampai tidak bersisa. ${ }^{13,6,2,12}$ Pada tahun atau interferon alfa $2 \mathrm{~b} 4 \mathrm{x}$ sehari selama 2012, Oellers \& L.Karp, ${ }^{2}$ menambahkan beberapa bulan memberikan hasil baik. penanganan dari Damato dan Coupland Kedua jenis kemoterapi topikal ini diatas dengan beberapa detail dibawah ini : diberikan sebagai terapi tambahan dan pada

\section{No touch technique}

Dipilih untuk menghindari penyebaran sel ganas, cryotherapy sampai batas margin 4-6 $\mathrm{mm}$ bebas tumor, penutupan konjungtiva dengan membran amnion untuk menghindari skar dan simblefaron, sklerektomi parsial dilakukan pada kasus dengan invasi sklera dengan meninggalkan membran bowman sebagai
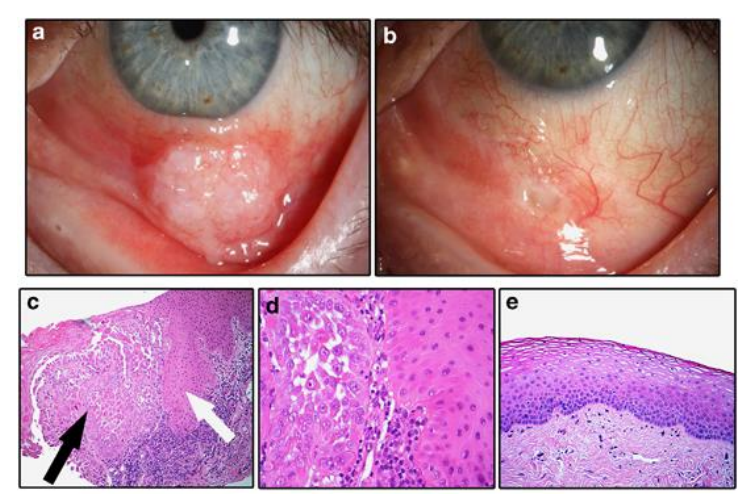
tumor yang tidak bisa dieksisi sepenuhnya atau sebagai terapi adjuvan pasca eksisi. ${ }^{28}$ Penggunaan mitomycin $\mathrm{C}$ topikal yang diencerkan dengan dosis $1000.000 \mathrm{IU} / \mathrm{ml}$ dapat diaplikasikan secara topikal beberapa kali sehari antara 6 minggu sd 6 bulan. ${ }^{29,24}$ Pada kondisi yang tidak bisa direseksi secara komplit karena besar atau sudah meliputi struktur orbita sekitar maka

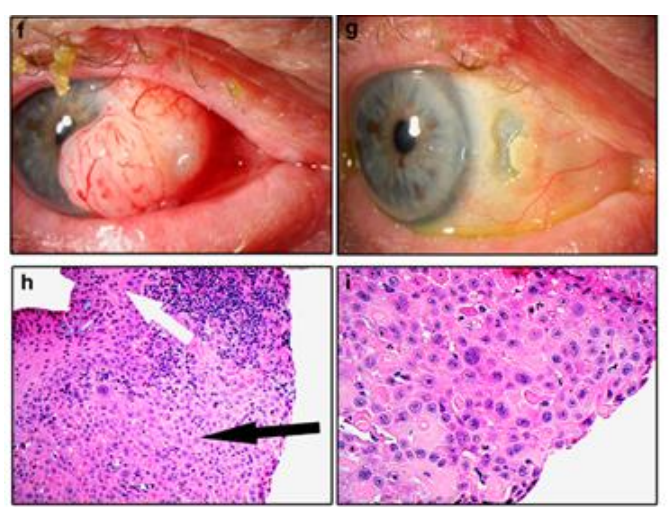

Gambar 7. Gambar a dan b kasus OSSN yang tidak bisa direseksi komplit dan 3 bulan pasca terapi dengan proton beam therapy (PBT). Gambar c, d gambaran histopatologi menunjukkan gambaran karsinoma sel squamosa. Gambar e pasca terapi PBT metaplasia squamousa tanpa dysplasia. Gambar f dan g OSSN besar yang juga mendapat terapi PBT dan 3 bulan pasca terapi. Gambar h dan I menunjukkan histopatologi karsinoma sel squamosa invasif ${ }^{\mathbf{3 0}}$.

barier metastasis. Antibiotik dan steroid bracytherapi menjadi pilihan masa depan 
yang sedang dikembangkan dengan hasil baik. ${ }^{30}$ Para ahli menyarankan bahwa terapi tetap disesuaikan dengan kondisi klinis dan hasil histopatologis. ${ }^{5,19}$

\section{KESIMPULAN}

Sebagai kesimpulan dari tinjauan pustaka ini, bahwa sampai saat ini etiologi OSSN bersifat multifatorial dan saling berinteraksi meliputi beberapa faktor seperti infeksi virus karsinogenik yaitu HPV, HIV, sinar ultraviolet $\mathrm{B}$, defisiensi vitamin A, kondisi imunodefisiensi, beberapa karsinogen seperti zat kimia, dan merokok. Diagnosis definitif OSSN ditegakkan dengan hasil histopatologis dari hasil biopsi eksisi atau insisi berupa conjunctival intraepithelial neoplasia (CIN), carcinoma in situ (CIS) dan karsinoma sel squamous invasif. Penanganan adalah dengan eksisi komplit dan dikombinasikan beberapa modalitas terapi yang bersifat individual dengan melihat kondisi klinis dan hasil pemeriksaan histopatologis.

\section{DAFTAR PUSTAKA.}

1. Holland EJ, Mannis MJ, Lee WB. Ocular Surface Disease California: Saunders Elsevier Inc.; 2013.

2. Oellers P, L.Karp C. Management of pigmented conjunctival lesions. The Ocular
Surface Journal. 2012; 10: p. 251-263.

3. Basti S, Macsai M. Ocular surface squamous neoplasia: a review. Cornea J. 2003 Oct; 22.

4. Chauhan S, Sen S, Sharma A, Dar L, Kashyap S, Kumar P, et al. Human papillomavirus: a predictor of better survival in ocular surface squamous neoplasia patients. Br J Ophthalmol. 2012 August; 96.

5. Xu, Zhou, Xu Y, Wang M, Liu F, Qu H, et al. The clinical value of in vivo confocal microscopy for diagnosis of ocular surface squamous neoplasia. Eye Journal. 2012 March; 21.

6. Mittal R, Suryasnata Rath GKV. Ocular surface squamous neoplasia - Review. Saudi J.Opthalmol. 2013; 27(177-186).

7. Gichuhi S, Ohnuma Si, Sagoo MS, Burton MJ. Pathophysiology of ocular surface squamous neoplasia. Experimental eye search J. 2014 August; 129.

8. Kim SK, Gombos DS, Esmaeli B. Managemen of conjunctival neoplasms. In Opthalmic oncology. 1st ed. New York: Springer; 2011. p. 127-139.

9. Simbiri KO, Murakami M, Feldman M, Steenhoff AP, Nkomazana O, Bisson G, et al. Multiple oncogenic viruses identified in Ocular surface squamous neoplasia in HIV 1 patients. Infectious Agents and Cancer J. 2010; 5(2).

10. Agaba A. Conjunctival squamous-cell carcinoma associated with HIV infection in Kampala Uganda. Lancet. 1995; 345.

11. Lee G, Hirst L. Incidence of ocular surface epithelial dysplasia in metropolitan Brisbane. A 10-year survey. Arch opthalmol J. 1992 April; 4.

12. Shield CL, Jerry. Tumor of conjunctiva and cornea. In Carol S, Jerry A. Atlas of Eyelid and Conjunctival Tumors. Philadelphia: Lippincott Williams \& Wilkin; 1999.

13. Ophthalmology AAo. AAO Clinical and basic science section 4. In Eye A. Ophthalmic Pathology and Intraocular Tumors. San Francisco; 2011-2012. p. 6264. 
14. Aoki, Tosato G. Neoplastic conditions in the context of HIV-1 infection. Curr.HIV Res J. 2004 Oct.

15. Varun Verma, Shen D, Sieving P, Chan CC. The role of infectious agents in the etiology of ocular adnexal neoplasia. Survey of Opthalmol. 2008 July August; 53.

16. Handoko SB, Supartoto A. Comparison of p-53 expresion in $\mathrm{HPV}(+)$ and $\mathrm{HPV}(-)$ in conjunctival and eyelid tumor. Jurnal oftalmologi Indonesia. 2007 Desember; 3.

17. Donnel M, McDonnel P, Sun Y. Human papillomavirus DNA in tissues and ocular surface swabs of patients with conjunctival epithelial neoplasia. Invest ophthalmol Vis Sci. 1992; 33.

18. Kiire C, Srinivasan S, Karl C. Ocular squamous neoplasia. In.Opthalmol Clin. 2010; 50.

19. Nguena MB, Tweel JGvd, Makupa W, Hu VH, Weiss HA, Gichuchi S. Diagnosing Ocular Surface Squamous Neoplasia in East Africa Case-Control Study of Clinical and In Vivo Confocal Microscopy Assessment. Am J Ophthalmol. 2014.

20. Mahomed A, Chetty R. Human Immunodeficiency Virus Infection, Bcl-2, p53 Protein, and Ki-67 Analysis in Ocular Surface Squamous Neoplasia. Clinical Sciences J. 2002 Mei.

21. Hirst L, Axelsen R, Schwab I. Pteriygium and associated ocular surface squamous neoplasia. Arch ophthalmol. 2009; 127.

22. Trosko J, Reeves FJ. Sunlight-induced pyrimidine dimers in human cells in vitro. Nature. 1970; 228.

23. Radhakrishnan A. Ocular Surface Squamous Neoplasia[OSSN] A Brief Review. Kerala J. of Ophthalmology. 2011 Dec; 23.

24. Woreta FA, Karp CL. Ocular surface Neoplasias. In J.Holand E, J.Manis M, Lee WB. Ocular Surface Disease. California: Saunders Elsevier; 2013. p. 145-149.

25. Tsatsos M, Karp CL. Modern Management of Ocular Surface Squamous Neoplasia. Expert Review of ophthalmology. 2013 August; 3 .

26. Rudkin A, Dodd T, Muecke J. The differential diagnosis of localised amelanotic limbal lesions; a review of 162 consecutive excisions. Br. J Ophthalmol. 2011; 95 .

27. Tanavuvat N, Lertprasertsuke N. Ocular Surface squamous neoplasia. www.intechopen.com. .

28. Damato B, Coupland SE. Management of conjunctival melanoma. Expert review anticancer. 2009;: p. 1227-1239.

29. Palacian MS, Martin EG, Tirado FF, Julvez LEP. Update and review of conjunctival melanoma treatment. Arch soc Esp Oftalmol. 2014; 88: p. 277-249.

30. El-Assal , Salvi SM, Rundle PA, Mudhar HS, Rennie IG. Treatment of invasive ocular surface squamous neoplasia with proton beam therapy. Eye J. 2013 August. 
Mahanani. Tumor Ocular Surface Squamosa Tinjauan Pustaka Mengenai Etiopatogenesis, Diagnosis Klinis, dan Histopatologis 